\title{
KAJIAN ETNOBOTANI TUMBUHAN MANGROVE OLEH MASYARAKAT KAMPUNG NIPAH DUSUN III DESA SEI NAGALAWAN KECAMATAN PERBAUNGAN KABUPATEN SERDANG BEDAGAI SUMATERA UTARA
}

\author{
1Rahmadani Lubis, ${ }^{1}$ Jamilah Nasution, ${ }^{2}$ E. Harso Kardhinata \\ ${ }^{1}$ Fakultas Biologi Universitas Medan Area, Jl. Kolam No. 1 Medan Estate 20223, Sumatera Utara \\ ${ }^{2}$ Fakultas Pertanian Universitas Sumatera Utara \\ jamilah.nasution83@gmail.com
}

\begin{abstract}
ABSTRAK
Penelitian Etnobotani tumbuhan mangrove di Kawasan Kampung Nipah Dusun III Desa Sei Nagalawan Kecamatan Perbaungan Kabupaten Serdang Bedagai Sumatera Utara. Bertujuan untuk mengetahui jenis-jenis tumbuhan mangrove yang dimanfaatkan oleh tiap Etnis. Metode yang digunakan dalam penelitian ini adalah metode deskriptif dengan metode survey dan tehnik wawancara semi terstruktur yaitu mengidentifikasi jenis-jenis tumbuhan mangrove yang dimanfaatkan. Data yang dicatat adalah nama lokal, nama latin, nama family bagian tumbuhan yang digunakan, dan cara pemanfaatannya. Hasil penelitian diperoleh 8 jenis tumbuhan dari 8 famili yang dimanfaatkan. Masing-masing famili hanya memiliki 1 jenis tumbuhan mangrove yaitu Acanthus ilicifolius (Acanthaceae), Avicennia marina (Avicenniaceae), Nypa fruticans (Arecaceae), Rhizophora apiculata (Rhizophoraceae), Scaevola tacada (Goodeniaceae), Hibiscus tiliaceus (Malvaceae), Strychnos sp (Loganiaceae) Morinda citrifolia (Rubiaceae).
\end{abstract}

Kata kunci : Etnobotani, Jenis Mangrove, Kampung Nipah.

\begin{abstract}
Research about mangrove ethnobotany in Kampung Nipah zone Dusun III Sei Nagalawan Perbaungan Bedagai Serdang District of North Sumatra. The aiming is determine the types of magrove plants are utilized by each of etnic. the method used in this research is descriftive with survey and interview semi-structure to indentify types mangrove plants are utilized. Data recorded from plants is the local name, latin name, family name part of the plant used, and how to use them. The results were obtained 8 species from 8 families were utilized. Each family contains only one species of magrove plants are : Acanthus ilicifolius (Acanthaceae), Avicennia marina (Avicenniaceae), Nypa fruticans (Arecaceae), Rhizophora apiculata (Rhizophoraceae), Scaevola tacada (Goodeniaceae), Hibiscus tiliaceus (Malvaceae), Strychnos sp (Loganiaceae), Morinda citrifolia (Rubiaceae).
\end{abstract}

Keywords : Ethnobotany, Mangrove species, Nypa village

\section{Pendahuluan}

Hubungan manusia dengan tumbuhan dan lingkungannya sebagai kebudayaan yang tercermin dalam realitas kehidupan disebut juga dengan Etnobotani. Etnobotani ini merupakan pengetahuan tradisional dalam memajukan kualitas hidup, tidak hanya bagi manusia tapi juga kualitas lingkungan karena nilai guna yang dimiliki dan digunakan. Studi tersebut bermanfaat ganda, karena selain bermanfaat bagi manusia dan lingkungan, dan jenisjenis tumbuhan yang digunakan oleh masyarakat (Suryadarma, 2008).

Menurut Arief (2003) dalam Ghufran (2012), hutan mangrove dikenal dengan istilah vloedbosh, kemudian dikenal dengan istilah " payau " karena sifat habitatnya yang payau, yaitu daerah dengan kadar garam antara 0,5 ppt dan $30 \mathrm{ppt}$. Disebut juga ekosistem hutan pasang surut karena terdapat di daerah yang dipengaruhi oleh pasang surut air laut.

Kampung Nipah Desa Sei Nagalawan Kecamatan Perbaungan Kabupaten Serdang Bedagai dipilih sebagai tempat penelitian karena kawasan ini memiliki keanekaragaman flora yang bermanfaat dan merupakan lokasi yang kaya akan hasil tumbuhannya seperti nipah (Nypa fructicans), jeruju (Acanthus ilicifolius), ketapang (Terminalia catappa), buta-buta (Excoecaria agallocha), api-api (Avicennia), bakau (Rhizophora) dan sebagainya. Namun akibat belum termanfaatkan tumbuhan mangrove oleh masyarakat Kawasan Desa Sei Nagalawan Kecamatan Perbaungan Kabupaten Serdang Bedagai ini secara maksimal sehingga keadaannya pun belum terealisasi dengan baik. Informasi tentang macam-macam tumbuhan mangrove yang dapat dimanfaatkan oleh msyarakat Kampung Nipah tersebut sangat diperlukan sebagai 
dasar untuk menentukan pengelolaan yang tepat sebagai upaya pelestarian serta pemanfaatan tumbuhan mangrove yang ada di Desa Sei Nagalawan Kecamatan Perbaungan Kabupaten Serdang Bedagai.

Tujuan dari penelitian ini adalah untuk mengetahui jenis-jenis tumbuhan mangrove yang dimanfaatkan dan pemanfaatannya oleh masyarakat Kampung Nipah Dusun III Desa Sei Nagalawan Kecamatan Perbaungan Kabupaten Serdang Bedagai.

\section{Bahan dan Metode}

Penelitian ini dilaksanakan pada bulan Februari 2016 s.d Mei 2016 di Dusun III Desa Sei Nagalawan Kecamatan Perbaungan Kabupaten Serdang Bedagai Sumatera Utara dan Laboratorium Biologi Universitas Medan Area.

Metode yang digunakan dalam penelitian ini adalah deskriptif dengan metode survey dan tehnik wawancara semi terstruktur yaitu mengidentifikasi jenis-jenis tanaman mangrove di Kampung Nipah Dusun III Desa Sei Nagalawan Kecamatan Perbaungan Kabupaten Serdang Bedagai. Wawancara semi terstruktur berpedoman pada daftar pertanyaan seperti nama lokal tanaman, bagian yang dimanfaatkan, manfaatnya, cara pemanfaatannya, dan lain lain (Rozak, 2011). Pemilihan responden dilakukan dengan metode teknik pengelompokkan dengan melihat etnis yang ada di daerah Dusun III Desa Sei Nagalawan yang terdiri dari 6 suku, yaitu suku Melayu, suku Banjar, suku Jawa, suku Mandailing, suku Sunda, dan suku Minang.

Pengambilan data dilakukan dengan cara wawancara semi struktur yang pertanyaannya disusun sedemikian rupa sehingga informasi memiliki keleluasan menjawab. Tehnik pemilihan informasi berdasakan informasi penduduk setempat. Data yang dicatat dari nama tumbuhan adalah nama lokal, bagian tumbuhan yang digunakan, dan cara penggunaannya (Idolo et al. 2009). Tahap wawancara ini juga mencatat data pendukung yang meliputi data tentang informan, yaitu nama, usia, pekerjaan, dan jenis kelamin (Martin 2004). Cara pemilihan responden dengan menanyakan kapada kepala Dusun dan masyarakat bagaimana cara pengolahan tanaman mangrove tersebut, pemilihan responden tidak ada pembatas bagi tiap-tiap suku dan melakukan wawancara sebanyak mungkin pada masyarakat Kampung Nipah Dusun III Sei Nagalawan.

Sampel yang didapat kemudian difoto perawakan tumbuhan mangrove ketika masih tertanam, bagian tumbuhan yang digunakan sebagai obat, bahan sandang pangan, penghasil kayu yang dibuat untuk bahan bangunan, akar bakau yang digunakan sebagai penghasil tinta batik.
Data yang diperoleh dari lapangan kemudian diolah secara deskriptif dengan tabulasi untuk mendaftarkan semua karakteristik jenis-jenis mangrove yang di identifikasi dengan menggunakan buku panduan pengenalan mangrove di Indonesia.

\section{Hasil dan Pembahasan \\ 1. Jumlah Responden dan Jenis Tumbuhan Mangrove}

Berdasarkan penelitian yang telah dilakukan di kawasan Kampung Nipah Dusun III Desa Sei Nagalawan diperoleh 6 etnis, yang terdiri dari 95 responden dari etnis yang berbeda. Hal ini dapat dilihat pada tabel di bawah ini:

Tabel 1. Etnis yang terdapat di Kampung Nipah Dusun III.

\begin{tabular}{ccc}
\hline No & Etnis & Jumlah responden \\
\hline $\mathbf{1}$ & Banjar & 45 \\
$\mathbf{2}$ & Melayu & 23 \\
$\mathbf{3}$ & Jawa & 21 \\
$\mathbf{4}$ & Mandailing & 2 \\
$\mathbf{5}$ & Sunda & 2 \\
$\mathbf{6}$ & Minang & 2 \\
& Jumlah & 95 \\
\hline
\end{tabular}

Dari hasil penelitian yang dilakukan diperoleh 8 jenis dan 8 famili tumbuhan mangrove yang dimanfaatkan oleh masyarakat untuk kehidupan sehari-hari. Masing-masing famili hanya memiliki 1 jenis tumbuhan mangrove. Terdiri dari mangrove sejati dan mangrove ikutan. Mangrove sejati yaitu jenis Jeruju (Acanthus ilicifolius) famili Acanthaceae, Api-api (Avicennia marina) famili Avicenniaceae, Nipah (Nypa fruticans) famili Arecaceae, Bakau tandok (Rhizophora apiculata) famili Rhizophoraceae. Mangrove ikutan yaitu jenis Bakung-bakung (Scaevola tacada) famili Goodeniaceae, Waru (Hibiscus tiliaceus) famili Malvaceae, kedera (Strychnos sp) famili Loganiaceae, Mengkudu (Morinda citrifolia) famili Rubiaceae.

\section{Tumbuhan Mangrove Yang di Manfaatkan Jeruju(Acanthus ilicifolius)}

Jeruju (Acanthus ilicifolius) famili Acanthaceae tergolong jenis tumbuhan mangrove sejati yang terdapat di Kampung Nipah yang selalu dimanfaatkan masyarakat untuk kebutuhan pangan dan obat-obatan. Jenis tumbuhan ini dimanfaatkan oleh Etnis Banjar, Melayu, Jawa, Mandailing, Sunda dan Minang. Bagian tumbuhan yang dimanfaatkan oleh semua etnis adalah daun. Khasiat daun jeruju bagi semua Etnis adalah sebagai pangan dan obatobatan. Sebagai pangan daun jeruju dapat diolah menjadi kerupuk dan teh sebagai obat-obatan. Teh jeruju yang dihasilkan dapat mengobati diabetes dan sesak nafas. 


\section{Api-api (Avicennia marina)}

Api-api (Avicennia marina) famili Avicenniaceae tergolong jenis tumbuhan mangrove sejati yang terdapat di Kampung Nipah yang memiliki manfaat sebagai pangan oleh semua etnis yaitu etnis Banjar, Melayu, Jawa, Mandailing, Sunda dan Minang. Bagian tumbuhan yang dimanfaatkan adalah buah. Kegunaan buah api-api pada masingmasing etnis adalah sebagai pangan. Buah yang dihasilkan dapat diolah menjadi dodol dan makanan ringan.

\section{Nipah (Nypa fruticans)}

Nipah (Nypa fruticans) famili Arecaceae tergolong jenis tumbuhan mangrove sejati yang terdapat di Kampung Nipah yang dimanfaatkan oleh semua etnis yaitu etnis Banjar, Melayu, Jawa, Mandailing, Sunda dan Minang. Bagian yang dimanfaatkan adalah daun dan buah nipah. Kegunaan daun nipah oleh semua etnis adalah sebagai papan berfungsi untuk atap rumah, sedangkan buah nipah digunakan sebagai pangan yang dapat diolah menjadi kolang kaling.

\section{Bakau tandok (Rhizophora apiculata)}

Bakau tandok (Rhizophora apiculata) famili Rhizophoraceae tergolong jenis tumbuhan mangrove sejati yang terdapat di Kampung Nipah yang dimanfaatkan oleh 4 etnis yaitu Etnis Banjar, Melayu, Jawa, Mandailing, sedangkan 2 etnis yaitu (Sunda dan Minang) tidak mengenal dan mengetahui manfaat tumbuhan bakau tersebut. Bagian tumbuhan yang dimanfaatkan adalah daun dan kulit batang. Khasiat daun bakau oleh etnis yang menanfaatkan adalah sebagai obat-obatan, contohnya daun bakau dihaluskan dan kemudian ditempelkan kebagian tubuh yang terluka. Sedangkan bagian kulit batang tumbuhan bakau digunakan sebagai industri, contohnya bahan membuat batik.

\section{Bakung-bakung (Scaevola tacada)}

Bakung-bakung (Scaevola tacada) famili Goodeniaceae tergolong jenis tumbuhan mangrove ikutan yang terdapat di Kampung Nipah dan dimanfaatkan oleh masing-masing etnis yaitu etnis Banjar, Melayu, Jawa, Mandailing, Sunda dan Minang sebagai obat-obatan. Bagian tumbuhan yang dimanfaatkan daun bakung-bakung biasanya digunakan sebagai obat pada semua etnis. Daun dikeringkan kemudian direbus tanpa menggunakan bahan campuran kemudian air rebusan tersebut diminum, khasiatnya untuk mengobati penyakit hipertensi dan luka dalam

\section{Waru (Hibiscus tiliaceus)}

Waru (Hibiscus tiliaceus) famili Malvaceae terdapat di Kampung Nipah yang dimanfaatkan oleh 4 etnis yaitu Etnis Banjar, Melayu, Jawa, Mandailing, sedangkan 2 etnis yaitu (Sunda dan Minang) tidak mengenal dan mengetahui manfaat tumbuhan waru tersebut. Bagian tumbuhan yang dimanfaatkan adalah daun dan getah. Cara penggunaan tiap masing-masing etnis sama. Khasiat daun dan getah waru oleh etnis yang memanfaatkan adalah sebagai obat-obatan, contohnya daun waru diremas hingga layu dan ditempelkan untuk mengobati sakit kulit seperti bisul, dan getah waru dioleskan untuk menghilangkan bisa hewan.

\section{Kedera (Strychnos sp)}

Kedera (Strychnos sp) famili Loganiaceae tergolong jenis tumbuhan mangrove ikutan yang terdapat di Kampung Nipah yang memiliki manfaat sebagai pangan yang dimanfaatkan oleh 5 etnis yaitu Etnis Banjar, Melayu, Jawa, Mandailing, Sunda, sedangkan 1 etnis yaitu (Minang) tidak mengenal dan mengetahui manfaat tumbuhan kedera tersebut. Bagian tumbuhan yang dimanfaatkan adalah buah. Kegunaan buah kedera pada masing-masing etnis yang memanfaatkan adalah sebagai pangan. Buah yang dihasilkan dapat diolah menjadi sirup.

\section{Mengkudu (Morinda citrifolia)}

Mengkudu (Morinda citrifolia) famili Rubiaceae tergolong jenis tumbuhan mangrove ikutan yang terdapat di Kampung Nipah yang memiliki manfaat sebagai obat oleh semua etnis yaitu Etnis Banjar, Melayu, Jawa, Mandailig, Sunda dan Minang. Bagian tumbuhan yang dimanfaatkan buah mengkudu biasanya digunakan sebagai obat pada masing-masing etnis. Buah dihaluskan dengan cara diparut dan air dari buah mengkudu tersebut disaring kemudian diminum, khasiatnya untuk mengobati penyakit kanker, diabetes dan gangguan pencernaan.

\section{KhasiatTumbuhan Mangrove}

Berdasarkan hasil yang diperoleh tentang manfaat tumbuhan mangrove yang digunakan oleh masing-masing etnis (Banjar, Melayu, Jawa, Mandailing, Sunda dan Minang) dalam kehidupan sehari-hari adalah pengobatan, pangan, papan, dan industri.

Khasiat tumbuhan mangrove sebagai pengobatan merupakan hal yang paling banyak digunakan oleh masing-masing etnis, yaitu untuk mengobati penyakit diabetes, sesak nafas, hipertensi, luka dalam, luka pada kulit, bisul, kanker, gangguan pencernaan dan menghilangkan bisa hewan. Bagian tumbuhan yang dimanfaatkan sebagai pengobatan adalah buah, daun dan getah. Masing-masing bagian tumbuhan yang dimanfaatkan memiliki cara pengolahan obat yang berbeda-beda. tergolong jenis tumbuhan mangrove ikutan yang 
Masyarakat Etnis Jawa, Etnis Melayu, Etnis Banjar, Etnis Mandailing, Etnis Minang dan Etnis Sunda di Kampung Nipah Dusun III Desa Sei Nagalawan Kecamatan Perbaungan Kabupaten Serdang Bedagai tinggal berdekatan sehingga masyarakat dapat saling berbagi informasi tentang pemanfaatan tumbuhan mangrove di wilayah tersebut. Hal ini menyebabkan informasi tentang pemanfaatan tumbuhan mangrove dapat meluas ke seluruh masyarakat, namun cara memanfaatkan tumbuhan mangrove di setiap etnis menjadi sama.

\section{Bahan Yang Terkandung Dalam Tumbuhan Mangrove Sejati}

a. Bahan yang terkandungdalam mangrove jeruju (Acanthus ilicifolius)

Kandungan kimia yang terdapat pada tanaman jeruju adalah saponin, flavonoida, dan polifenol yang banyak terdapat pada daun, akar dan biji pada Acanthus ilicifolius. Selain itu bijinya juga mengandung alkaloida, yang dapat bermanfaat untuk mengobati berbagai penyakit yakni mengobati sakit perut, dan juga penyakit cacingan. Daun jeruju mengandung senyawa verbaskosida dan asam fenolat (Soetarno, 2007)

b. Bahan yang terkandungdalam mangrove Api-api (Avicennia marina)

Menurut penelitian yang dilakukan Wibowo et al.(2009) terhadap jaringan tanaman mangrove api-api menunjukkan bahwa mangrove api-api mengandung senyawa-senyawa aktif yaitu alkaloid, saponin, tanin, plafonoid, triterpenoid, dan glukosida. Daun mangrove api-api (Avicennia marina) merupakan salah satu tumbuhan yang dimanfaatkan sebagai bahan pakan ternak dan dipakai sebagai obat anti fertilitas tradisional oleh masyarakat pantai (Wijayanti, 2008).

c. Bahan yang terkandungdalam mangrove nipah (Nypa Fruticans)

Pada umumnya tanaman nipah mengandung polifenol, tanin dan alkaloid. Selain itu, kandungan zat panghambat peroksida lipid pada nipah menunjukkan aktivitas yang kuat. Peroksida lipid berperan dalam proses penuaan dan beberapa penyakit kronis termasuk diabetes, gangguan saraf, kardio (penyakit pembuluh darah) dan kanker. Tanaman nipah berkhasiat sebagai penghambat penyakit tuberkulosi, penyakit hati, sakit tenggorokkan dan sebagai penawar racun (Rahmatullah et al., 2010).

d. Bahan yang terkandungdalam mangrove bakau tandok (Rhizophora apiculata)

Ekstrak kasar metanol dan kulit kayu Rhizophora apiculata memiliki senyawa aktif sebagai inhibitor tirosinase dan antioksidan yang diketahui merupakan merupakan senyawa isoflavon (Abdullah, 2011). Peneliti lain mengemukakan ekstrak kloroform kulit batang tumbuhan Rhizophora apiculata memiliki aktivitas biolarvasida terhadap larva Aedes aegypti. Ekstrak kasar etanol dari tanaman bakau memiliki aktivitas anti bakteri patogen, Escherichia coli, $P$. aeruginosa , $K$. pneumonia, Enterobacter sp dan Streptococcus aureus dengan menggunakan metode disk diffusion (Ravikumar et al., 2010).

e. Bahan yang terkandungdalam mangrove Waru (Hibiscus tiliaceus)

Kandungan kimia dan kegunaan tumbuhan waru dalam pengobatan tradisional, akar waru di gunakan sebagai pendingin bagi sakit demam, dan waru membantu pertumbuhan rambut, sebagai obat batuk, obat diare berdarah atau berlendir, amandel. Bunga di gunakan untuk obat trakhoma dan masuk angin. Kandungan kimia daun dan akar waru adalah saponin dan flavonoid. Di samping itu daun juga paling sedikit mengandung 5 senyawa fenol, sedang akar waru mengandung tanin (Syamsuhidayat dan Hutapea, 1991).

\section{Kesimpulan}

Berdasarkan hasil penelitian yang diperoleh dapat disimpulkan bahwa terdapat 8 jenis tumbuhan dari 8 familiyang dimanfaatkan oleh masyarakat di Kampung Nipah Dusun III Desa Sei Nagalawan. Masing-masing famili hanya memiliki 1 jenis tumbuhan mangrove, yaitu jenis Jeruju (Acanthus ilicifolius) famili Acanthaceae, Api-api(Avicennia marina) famili Avicenniaceae, Nipah (Nypa fruticans) famili Arecaceae,Bakau tandok(Rhizophora apiculata) famili Rhizophoraceae, Bakung-bakung (Scaevola tacada)famili Goodeniaceae, Waru (Hibiscus tiliaceus) famili Malvaceae, kedera (Strychnos $s p$ ) famili Loganiaceae. Mengkudu (Morinda citrifolia) famili Rubiaceae. Tumbuhan yang dimanfaatkan bagian daunnya ada 4 jenis, bagian buah ada 3 jenis, bagian getah dan kulit batang masing-masing 1 jenis.

Khasiat tumbuhan mangrove sebagai pengobatan untuk mengobati penyakit diabetes, sesak nafas, hipertensi, luka dalam, luka pada kulit, bisul, dan menghilangkan bisa hewan. Sebagai pangan dapat diolah menjadi kerupuk, dodol, makanan ringan, kolang kaling, dan sirup. Sebagai papan berfungsi untuk atap rumah serta penghasil industri yang dapat digunakan untuk membuat batik.

\section{Daftar Pustaka}

Abdullah. 2011. Potency of Rhizophora apiculata as Tyrosinase Inhibitors and Antioxidants. Skripsi. Institut Pertanian Bogor

Arief, A. 2003. Hutan Mangrove, Fungsi dan Manfaatnya. Kanisius Yogyakarta 
Ghufran, M. 2012. Ekosistem Mangrove Potensi, Fungsi, dan Pengelolaan. PT. Rineka cipta. Jakarta

Idolo, M, R Motti dan S Mazzoleni. 2009. Ethnobotanical and Phytomedicinal Knowledge In a Long-history Protected area of the Abruzzo. Lazio, and Molise National Park (Italian Appenines) Journal of Ethnopharmacology (127) 379-395

Martin G.J. 2004. Ethnobotan y, A People and Plants Conservation Manual. Chapman and Hall, London

Noor Y. R, M. Khazali dan I. N. N. Suryadiputra. 1999. Panduan Pengenalan Mangrove di Indonesia Institute Pertanian Bogor

Rahmatullah, M., Sadeak, Sk.Md.I., Bachar S.C., Hossain, Md.T., Al-mamun, A., Montaha, Jahan, N., Chowdhury, M.H., Jahan, R., Nasrin, N., Rahman, M., dan Rahman, S. 2010. Brine Shrimp Toxicity Study of Different Bangladeshi Medical Plants. American Eurasian Network for Scientific Information. Advences In Natural And Applied Sciences

Ravikumar S, Gnanadesigan M, Suganthi P, Ramalakshmi A.2010. Antibacterial Potential of Chosen Mangrove Plants Against Isolated Urinary Tract Infectious Bacterial Pathogens. International Journal of Medicine and Medical Sciences Vol

Rozak, Abdur. 2011. Studi Etnobotani Tumbuhan yang Berpotesi Sebagai Obat Penyakit dalam di Kecamatan Guluk-guluk Kabupatn Sumenep. Madura. Skripsi. Universitas Islam Negeri Maulana Malik Ibrahim

Soetarno, S., 2007. Verbaskosida dan Asam Fenolat dari Daun Jeruju (Acanthus ilicifolius) Suatu Tumbuhan Mangrove. Http://digilib.biologi.lipi.go.id (9 Maret 2009)

Suryadarma, M.S. 2008. Diktat Kuliah Etnobotani. (online) Jurusan Pendidikan Biologi Fakultas Matematika dan Ilmu Pengetahuan Alam Universitas Negri Yogyakarta : Yogyakarta

Syamsuhidayat, S.S dan Hutapea, J.R. 1991. Inventarisasi Tanaman Obat Indonsia (I). Departemen kesehatan RI : Jakarta

Wibowo, C., C. Kusmana, A. Suryani, Y. Hartati P. Oktadiyani, 2009. Pemanfaatan Pohon Mangrove Api-api (Avicennia spp) sebagai Bahan Pangan dan Obat. Fakultas Kehutanan IPB

Wijayanti ER. 2007. Pengaruh Pemberian Ekstrak Daun Api-api (Avicennia Marina) Terhadap Resorpsi Embrio Berat Badan Dan Panjang Badan Janin Mencit (Mus musculus) Skripsi, Universitas Airlangga, Indonesia. 